\title{
人身傷害保険に扮ける疾病の扱い
}

——ーード・パーティ型制度との比較から

\section{佐 野誠}

\section{ロアブストラクト}

本稿は，自動車事故に疾病が関与した場合の被害者救済について人身傷害 保険とサード・パーティ型制度との比較を行うことにより，人身傷害保険の 商品性の観点から同保険における疾病の扱いを再検討するものである。

自動車事故に疾病が関与するケースとしては, 被害者の疾病が事故の一因 となった場合と, 事故による被害者の傷害が同人が有していた既存の疾病に より重篤となった場合が考えられるが，いずれの場合でも，人身傷害保険の 給付がサード・パーティ型制度からの給付を下回る可能性がある。これは, 人身傷害保険が従来型の傷害保険として構成されていることに由来する。

ファースト・パーティ型ノーフォルト保険によるサード・パーティ型制度 の代替という人身傷害保険のコンセプトからすると, 約款を見直して疾病リ スクを取り込むことにより被害者救済のレベルを向上させることが考えられ る。

\section{ロキーワード}

人身傷害保険, 疾病起因性, 素因減額

\section{1.はじめに}

人身傷害保険は, 自動車事故被害者に対してその損害を填補するファース ト・パーティ型ノーフォルト保険である。それは, 従来, 加害者が付保する /平成27年 5 月 27 日原稿受領。 
人身傷害保険に㧍ける疾病の扱い

サード・パーティ型保険である対人賠償責任保険（および自賠責保険）がカ バーしてきた部分を被害者自身が付保する保険によりカバーするものであり， その意味で，人身傷害保険は対人賠償責任保険の裏返しの保険であるともい える。しかし，人身傷害保険のカバー範囲は対人賠償責任保険のそれと必ず しも一致するものではない。カバー範囲の設定方法が違うからである。対人 賠償責任保険のカバー範囲は損害賠償責任法制および責任保険約款によって 規定されるのに対して, 人身傷害保険は傷害保険として構成されているので 傷害保険約款によりカバー範囲が規定されることになる1)。

もっとも，一般的な自動車事故の場合にはこの差異が顕在化することは少 ない。自動車事故により人身傷害が発生した場合には，通常，自動車の運行 によって他人の生命又は身体を害した（自賠法 3 条）といえるので損害賠償 責任（運行供用者責任）が発生し自賠責保険や任意対人賠償責任保険が発動 するであろうし，自動車の運行に起因する急激かつ偶然な外来の事故 ${ }^{2)}$ とい えるので人身傷害保険も発動するであろう。

一方で，自動車事故の原因や結果に被害者の疾病が関係している場合には， 両者における取り扱いが異なる可能性がある。具体的には, (1)自動車事故の 原因に疾病が関与している場合，および，(2)自動車事故による被保険者の傷 害が同人が有した既存の疾病により重篤となった場合，である。

このうち, (1)は疾病起因性の問題である。被害者の疾病が自動車事故の原 因の一つであった場合には，損害賠償においては加害者責任の阻却事由や賠 償額減額事由となりうるであろう。これに対して, 人身傷害保険は傷害保険 の一種であるので，外来の事故による傷害に対して保険金が支払われるので あり，疾病によるものは担保対象外となるはずである。ところが近時，疾病 起因性についての最高裁判例によって, 疾病が自動車事故の原因である場合

1）なお，人身傷害保険はノーフォルト保険であるので，自賠法 3 条の免責三要 件により加害者が免責される場合や過失相殺が行われる場合に対人賠償責任保 険とカバー範囲が異なることは当然である。

2）東京海上日動火災保険株式会社・総合自動車保険約款第 2 章第 1 節第 1 条 $(2)$ (2014年10月 1 日版)。 
でも人身傷害保険金が支払われる可能性が出てきだ”。

一方，(2)は，自動車事故の損害賠償における素因減額の問題が，人身傷害 保険に抒いてどのように取り扱われるかという問題である。これは，従来， あまり議論されてこなかった問題であるが, 最近, いくつかの下級審判例が 出てきた。

本稿では，これら二つの問題について，損害賠償の局面と人身傷害保険の 局面とでそれぞれどのような扱いがなされるのかを検証し，損害賠償からの 填補と人身傷害保険のカバーとの間に齟龉が発生することにより，サード・ パーティ型制度からの救済よりも人身傷害保険からの給付の方が手薄くなる 可能性があることを示す。そして, それを踏まえたうえで, 人身傷害保険に おける疾病の扱いのあり方を再検討する。

\section{2. 事故の疾病起因性}

\section{（1）損害賠償の局面}

まず，自動車事故の発生に被害者の疾病が関与した場合を考える。たとえ ば，被害者が自動車を運転中に心疾患やてんかん等で意識を消失し，これに よって衝突事故を起こしたというケースである ${ }^{4)}$

この場合，相手方車両が存在しない自損事故（側壁への衝突，河川への転 落等）であれば，加害者となるべき者がいないので損害賠償の問題は発生し ない。一方，車両間の衝突の場合には，相手方車両の運行供用者責任が問題 となりうる。この場合, 相手方車両の運転者等の運行供用者は, 自賠法 3 条 の免責三要件を立証しない限り有責となる。

免責三要件のうちここで問題となるのは，「自己及び運転者が自動車の運

3）これに対して，人身傷害保険約款に疾病免責条項をあらたに挿入する損害保 険会社の動きがあることは後述のとおりである。

4）今一つ考えられるケースとしては，歩道を歩いていた人身傷害保険の被保険 者である歩行者が心疾患等により意識を消失して車道に倒れこみ, 走行してき た加害車両に礫過されたような場合である。この場合も, 加害者の損害賠償責 任という観点からは，車両間衝突事故とほぼ同様に考察できると思われる。 
人身傷害保険における疾病の扱い

行に関し注意を意らなかったこと」(第 1 要件)，および「被害者又は運転者 以外の第三者に故意又は過失があったこと」(第 2 要件) である。

第 1 要件については, 相手方車両の運転者が運転操作によって被害車両と の衝突を避けることができたのかどうかが問題となる。被害車両の運転者が 意識喪失し, 被害車両が制御不能となったとすると, 相手方車両の運転者の 無過失が認められる場合も考えられる。

一方，第 2 要件については，被害者の疾病を被害者の過失と同視できるか どうかが問題となる。条文の文言からすると, 過失と疾病はあきらかに異な るが，被害者の疾病も被害者側で発生した事由により事故原因となったとい う意味では被害者の過失と同様に評価してもよいかもしれない。一方で，被 害者救済という自賠法の理念からすると，条文を被害者側に不利に拡張解釈 することは問題であるとも考えられる。疾病については, 被害者に帰責性を 問いうる過失とはやはり異なると言わざるを得ないであろう。もっとも, 被 害者がてんかんの発作が抏こりうることを認識しながら自動車の運転をして いたというような場合には, 被害者の過失を認定することができることもあ りうる。

なお，自賠法で明記された免責三要件以外にも，学説上，不可抗力と正当 防衛が運行供用者責任に拈ける独立の免責事由とされている ${ }^{5)}$ 。しかし, こ こでいう不可抗力とは, 地震, 落雷, がけ崩れ, 野獣の飛び出し, 野鳥の襲 来などが想定されており ${ }^{6)}$, 被害者の疾病を不可抗力とすることは困難なよ うに思える。

以上を勘案すると，被害者の疾病に起因する自動車事故であっても，相手 方車両の運行供用者の責任は発生する可能性が高い。もっとも, このように 運行供用者責任が認められる場合であっても, 被害者の疾病が事故の一因と なっていることから，後述の素因減額と同様，過失相殺規定の類推適用によ

5）加藤一郎編 ·注釈民法（19）債権（10）103頁［池田浩一］（有斐閣， 1965）。

6）篠田省二「自賠法に扮ける免責」吉岡進編・現代損害賠償法講座 3 交通事故 151頁（日本評論社，1972）。 
り賠償額が減額されることは考えられる。

\section{（2）人身傷害保険の局面}

ア 約款規定

一方, 人身傷害保険はノーフォルト保険であるので, 相手方のある事故と 自損事故とで区別する必要はない。そこで，以下では疾病に起因した自損事 故を例にとって検討する。すなわち, 被保険者が自動車を運転中に心疾患 や癭痛発作のために意識不明となり，そのため自動車が操縦不能となって壁 に激突し，それによって被保険者が死亡したというような場合である。

これは人身傷害保険の約款解釈の問題である。現行の人身傷害保険の約款 では，保険給付の対象となる保険事故（人身傷害事故）とは，自動車または 原動機付自転車の運行に起因する事故等で，かつ，急激かつ偶然な外来の事 故により，被保険者が身体に傷害を被ることとされている7)。

この「急激かつ偶然な外来の事故」という文言は，わが国の損害保険会社 の傷害保険契約において保険事故を規定するために伝統的に使用されてきた 文言であり ${ }^{8)}$ ，人身傷害保険の約款においてもこの文言を使用している。こ こで「外来の事故」と限定する意味は，従来の通説では，身体に生じた事故 が身体の内部に原因があるのではなく，外部からの作用に原因があることを 要件とするものであり, 疾病による身体の事故を傷害から除外することに要 件としての意味があるとされてきた ${ }^{9)}$ 。そして，このような理解を前提とし て, 事故原因に疾病が関与した場合の外来性要件の成否が議論されてきた。

7）東京海上日動火災社約款・前掲注2）第 2 章第 1 節第 1 条。なお，人身傷害 保険の約款文言は損害保険各社により若干異なるが,この部分は他社もほとん ど同様である。

8）これに対して，わが国の生命保険会社の傷害保険の約款では「急激かつ偶発 的な外来の事故」という文言を使用しているが，その意味するところは損害保 険会社の傷害保険約款文言と同じである。

9）山下友信・保険法454頁（有斐閣，2005）。 
人身傷害保険における疾病の扱い

イ従来の議論

この議論においては, 原因としての疾病と結果としての身体傷害との間の 相当因果関係の有無が問題とされている。たとえば, 被保険者が心臓発作で 倒れたところに自動車が走行してきてこれに轢かれて死亡したような場合に は，疾病と死亡との相当因果関係を認めることは困難であり，この場合は事 故による死亡であるとして保険者有責という説が主流である ${ }^{10)} 。 一$ 万， 入浴 中に疾病の発作で意識不明となり風吕桶の中で溺死したような場合には，日 常生活で通常行われる入浴というプロセスの中で疾病による発作が生じてそ れをもつぱらの原因として溺死しているのであるから，自動車に轢かれたケ ースとは同日に論じられず，死亡は疾病による結果であるとみるべきとする 主張もある ${ }^{11)}$ 。

いずれにしても，この従来の議論は，事故の原因として疾病が関与した場 合には, 原因疾病と結果としての身体傷害との間の因果関係を問題としてお り，その意味で外来性の有無の判断に間接原因である疾病の影響を考慮する という判断枠組みをとっている。また, 従来の下級審判例においても, 有無 責判断の結果は異なっているが，判断枠組みとしてはこのような学説のそれ と同一であった ${ }^{12)}$ 。

なお，従来の人身傷害保険においては疾病免責条項が挿入されていなかっ たが，それ以外の主な傷害保険（普通傷害保険等）においては疾病免責条項 が入っていた。その場合, 外来性要件と疾病免責条項とが同じ内容を規定し ていることになり，その二つの関係が問題となる（ただし，外来性要件の立

10）江頭憲治郎・商取引法［第 7 版］526頁（弘文堂，2013）では，疾患による 発作が生じた場所が悪かったため外来的力が作用した場合等には保険金の支払 いを認めるべきであるとする。一方，加瀬幸喜「保険事故一外来性」傷害保険 の法理90頁（損保総研, 2000）は, 疾病の発作のみでは被保険者は死亡しなか ったと思われる場合には保険者有責とすべきとする。

11）山下·前掲注 9）482頁。

12）従来の下級審判例については, 佐野誠「判批」損保研究 69 巻 3 号 240 頁 (2007)。 
証責任は保険金請求者にあり，疾病免責の立証責任は保険者にある)。これ については, 疾病免責条項は念のための規定であり, 疾病の影響についての 立証責任は，外来性要件の立証責任者である保険金請求者にあるという理解 が一般的であった ${ }^{13)}$ 。

このような理解を前提として，上記の設例（心疾患等による意識障害が原 因となって発生した自動車事故による被保険者の死亡）における有無責を検 討してみると, 被保険者の死亡という結果の直接の原因は自動車事故である が，その自動車事故の原因（被保険者死亡の間接原因）は疾病である。すな わち，ここでの問題は疾病が死亡の「間接原因」である場合に疾病起因性が 認められるのかということになる。そして，そのことは疾病と死亡との間の 因果関係の有無の問題であり，どのような因果関係論を採用するかにより結 果が異なりうる ${ }^{14)}$ 。

ウ 最高裁判例

しかし, 近時, 最高裁は全く別の解釈を示した（最判（二小）平成19年 7 月 6 日民集 61 巻 5 号 1955 頁 $^{15)}$ ，最判（二小）平成19年10月19日判時1990号 144頁 $\left.{ }^{16)}\right)$ 。すなわち, 外来性とは被保険者の身体の外部からの作用によるも のを意味するだけであり, 疾病に起因しないという要件は含まないというも

13）佐野·前掲注12）244頁。

14）保険契約における各種の因果関係論については，佐野誠「傷害保険における 外来性要件と疾病免責条項」石田重森編著・保険学のフロンティア 238 頁（慶 應義塾大学出版会, 2008）参照。

15）本判例の判批として，中村心・ジュリ1351号109頁（2008），永石一郎・金商 1285号10頁 (2008), 白井正和 - 法学協会雑誌125巻11号234頁 (2008), 山野嘉 朗・ジュリ1354号119頁 (2008)，竹湏修・私法判例リマークス37号108頁 (2008), 藤井正夫 ·別冊判夕 22 号172頁 (2008), 榊素宽 - 判例時報2036号158 頁 (2009), 中村心・法曹時報62巻 3 号187頁（2010），鈴木達次・別冊ジュリ 202号（保険法判例百選）198頁（2010）。

16）本判例の判批として, 肥塚肇雄 - 民商法雑誌 138 巻 $4=5$ 号616頁 (2008), 山下典孝・速報判例解説（法学セミナー増刊） 2 号143頁（2008）, 加瀬幸喜 · 法律のひろば62巻 1 号57頁（2009）, 榊素寞・判例時報2036号158頁 (2009), 
人身傷害保険における疾病の扱い

のである。これによれば, 間接原因が疾病であっても, 死亡が自動車事故と いう外部からの作用によるものであれば外来性要件を充たすことになり，疾 病起因性の問題は外来性要件ではなく疾病免責条項の問題となる。したがっ て，当該傷害保険契約に疾病免責条項が付されていない場合には，このケー スでは保険者有責となる。このような解釈は, 従来の下級審判例や学説の趨 勢からはかなり異なったものであった

工 最高裁判例後の下級審判例の動向

上記二つの最高裁判例の後，いくつかの下級審判例が出されているが，い ずれも基本的に最高裁判例に準拠しているとみられる うに，最高裁判例の解釈と一致しているのか疑問があるものも存在する。

大阪地判平成20年 6 月 25 日（交民 41 巻 3 号764頁）は，心臓病の既往症の ある被保険者が自動車事故で死亡した事案であるが, 判旨は「疾病により本 件事故の有無にかかわらず死亡していた可能性を否定できないときは外来の 事故とはいえない」とした。最高裁判例によれば，疾病の状況がどうあれ， 自動車事故と傷害との間に相当因果関係が認められれば外来の事故といえる はずであるが，その意味では，本判例は最高裁判例と矛盾するようにみえる。 東京高判平成22年 4 月 28 日（事例研レポ255号11頁）は，アルツハイマー 型認知症である生命保険会社の傷害保険契約の被保険者が蒲鉾を誤飲し窒息 死した事案であるが, 判旨は「事故の原因がもっぱら疾病であるときは外来 性の事故ということはできない」としつつ，本件ではかまぼこ誤飲事故がも つぱらアルツハイマー型認知症によるとは認められないとして外来性は肯定 し, 一方で「疾病による嚥下障害, 精神神経障害の状態にある者の嚥下によ

甘利公人·石田満編 ·保険判例2009, 15頁（保険毎日新聞社, 2009), 増永謙 一郎・別冊判夕25号152頁（平成20年度主要民事判例解説）（2009），潘阿憲 · 別冊ジュリ202号（保険法判例百選）84頁（2010）。

17）私見ではこの最高裁判例の考え方に疑問を持っている（佐野誠「傷害保険に おける外来性問題一約款解釈と判例動向一」賠償科学39号29頁 (2013))。

18）最高裁判例以降の下級審判例については，佐野・前掲注17）28頁参照。 
る気道閉塞または窒息」という除外条項に該当するので免責とした。最高裁 の解釈によれば，事故の原因がもっぱら疾病であっても，それによって発生 した事故と傷害との間に相当因果関係が認められる限り外来性は認められる ことになるので，上記下線部分については最高裁判例に反するのではないか と考えられる。

\section{オ 損害保険会社の対応と新約款の解釈}

一方, 損害保険会社は最高裁判例を受けて, 従来疾病免責条項が入ってい なかった人身傷害保険に新たに疾病免責条項 ${ }^{19)}$ を挿入した ${ }^{20)}$ 。

この免責条項の解釈において問題となるのは, 被保険者の疾病等と自動車 事故との間の因果関係が認められるか否かである。すなわち，従来の学説・ 下級審判例では外来性要件において議論されてきた因果関係の問題が，今度 は疾病免責条項の適用において問題とされることになる。

この場合，保険契約における因果関係論の通説と思われる相当因果関係 説 $^{21)}$ によれば，疾病による意識消失により自動車事故が発生することが通常 であれば相当因果関係が認められて保険者免責となろう。意識消失から自動 車事故が発生することが「通常」かどうかは具体的な状況によって異なるで あろうが，一般的には運転者の意識が消失するような事態になれば，相手方 運転者の運転操作によりその車両との衝突事故は回避されることがあるとし ても，いずれ何らかの事故（自損事故を含む）が発生するであらうから，ほ とんどのケースでは保険者免責となろう。

19）東京海上日動社約款・前掲注2）第 2 章第 3 条（1）。

20）すべての損害保険会社の約款を調査したわけではないが，少なくとも大手損 保会社の人身傷害保険約款では疾病免責条項が新たに挿入されている。一方, 生命保険会社の傷害保険では依然として疾病免責条項は入っていないようであ る。

21）「ある事実から別の事実が発生することが当該事例においてのみならず他の 一般的な場合でも同様といえる場合に相当因果関係説がある」と説明されてい る（山下・前掲注9）383頁)。 


\section{3. 既存疾病による傷害の重篤化}

\section{（1）損害賠償の局面}

人身傷害保険と疾病をめぐる次の問題は, 自動車事故による被害者の傷害 が，被害者が罹患していた既存の疾病により重篤となった場合である。

このようなケースは，損害賠償の実務においては素因減額，あるいは素因 減責の問題として民法722条 2 項（過失相殺）を類推適用するという扱いが 定着している ${ }^{22)}$ 。ここでいう素因とは「被害者が被害を受ける以前から有し ていたところの当該被害を誘発または拡大する性質をもつ何らかの体質的原 因 $\left.^{23)}\right\lrcorner$ と説明されているが，賠償実務では，体質的原因以外に心因的原因に ついても素因として扱われている。そこで，素因としては，(1)心因的原因， (2)体質的原因のうち疾患, (3)体質的原因のうち身体的特徵, (4)加齢によるも の,の 4 種類が挙げられることになる。

従来の最高裁判例によれば, (1)心因的原因 ${ }^{24)}$ と, (2)疾患 ${ }^{25)}$ について民法 722 条 2 項の類推適用による減額を認め, 一方, (3)身体的特徴 ${ }^{26)}$ について 減額を認めていない。なお，(4)加龄については特に判示された判例はないよ うであるが, (2)疾患と(3)身体的特徴のいずれに該当するかにより減額の可否 が判断されるように思われる。もっとも，同じ体質的原因である疾患と身体 的特徴との区分は，具体的な事例においては困難な場合もある。

そこで, 自動車事故による傷害が, 被害者が有していた疾病により重篤と なった場合の具体例として, 被害者が運転していた自動車に加害者が運転し

22）素因減額についての近時の文献として，森健二「交通損害賠償における「あ るがまま」」判夕1326号38頁（2010），永下泰之「損害賠償法における素因の位 置 (6 ·完)」北大法学論集65巻 1 号89頁 (2014), 石橋秀起・不法行為法にお ける割合的責任の法理（法律文化社，2014），窪田充見「判批」別冊ジュリ 224 号（民法判例百選 II 債権）204頁（2015）等。

23）平井宜雄・債権各論 II 不法行為159頁（弘文堂, 1992）。

24）最判昭和63年 4 月 21 日民集 42 巻 4 号243頁。

25）最判平成 4 年 6 月 25 日民集 46 巻 4 号 400 頁。

26）最判平成 8 年10月 29 日民集50巻 9 号2474頁。 
ていた自動車が追突したが，通常であれば被害者の傷害はむちうち症（外傷 性頸部症候群）程度であると判断されるところ, 被害者が重度の心臟疾患を 有していたために死亡してしまったというケースを考える。この場合，最判 平成 4 年 6 月 25 日 $^{27)}$ の判旨からすると，過失相殺規定を類推適用して，心臓 疾患が死亡という結果発生に寄与した割合を損害賠償額から控除することに なりそうである。もっとも，同判旨には「当該疾患の態様，程度などに照ら し，加害者に損害の全部を賠償させるのが公平を失するとき」という条件が 付されており，この部分の解釈次第では素因減額の可否の判断に影響を与え ることもありうると思われる。

\section{（2）人身傷害保険の局面}

ア 約款規定

上記で取り上げた具体例，すなわち，被保険者である被害者が運転してい た自動車に加害者が運転していた自動車が追突したが，通常であれば被害者 の傷害はむちうち症（外傷性頸部症候群）程度であると判断されるところ， 被害者が重度の心臓疾患を有していたために死亡してしまったという場合， 人身傷害保険においてはどのように取り扱われるか。

現在の損害保険実務においては，このようなケースには以下の条項 ${ }^{28)}$ (以 下「限定支払条項」という。）を適用することが通常であると思われる。

当会社は，下表のいずれかに該当する事由により，第 1 条（この条項の補 償内容）(2)の傷害が重大となった場合は，その事由がなかったときに相当 する額を損害の額として決定して保険金を支払います。

(1)被保険者が第 1 条(2)の傷害を被った時に, 既に存在していた身体の障 害または疾病が影響したこと

これによれば，人身傷害保険では死亡保険金は支払われず，被保険者が心

27）前掲注25)。

28）東京海上日動火災社約款・前掲注2）第 2 章第 4 条（7）。 


\section{人身傷害保険に㧍ける疾病の扱い}

臓疾患を有していなかったであれば被ったであろう損害を仮定して，傷害保 険金や後遺障害保険金を算定して支払うことになる。

ここで注意すべきは，この限定支払条項によれば，かならずしも既存の疾 病や障害の寄与率に比例した減額になるのではないということである。すな わち，被害者の被つた損害が傷害のみであり，元の傷害による入院日数が 10 日間，既存疾病による加重部分が10日間というような場合には，既存疾病の 寄与率に比例した減額が行われることになるが, ここで想定したような元の 事故では傷害のみであるにもかかわらず既存疾病によって加重されたことで 死亡という結果が生じたような場合には，死亡保険金の割合的減額が行われ るわけではない。

その意味で，損害賠償の局面での素因減額の結果と，人身傷害保険の局面 での限定支払条項適用の結果は必ずしも一致しない。

また，限定支払条項は，損害賠償の局面での素因減額と結果的に同じ機能 を有することもあるが，素因減額を規定した条項ではない。素因減額は損害 の負担における加害者と被害者の間の衡平という理念から行われるものであ るのに対して，限定支払条項はそのような理念から規定されているのではな い。あくまで，疾病ではなく事故による身体障害を担保するという傷害保険 の保険商品としての特性から規定されたものである。

その意味で，この限定支払条項は損害保険会社が引き受けている傷害保険 約款に一般的に付されているものであり ${ }^{29)}$ ，人身傷害保険に特有の規定では ない。本条項は自動車保険中の他の傷害保険，すなわち，自損事故保険 ${ }^{30)} ゃ$ 搭乗者傷害保険 ${ }^{31)}$ にもっている ${ }^{32)}$ 。

なお，生命保険会社の傷害保険においてはこのような限定支払条項は規定 されていない。その一方で, 対象となる不慮の事故の定義の中で「急激かつ

29）たとえば，損害保険料率算出機構が策定した標準約款の傷害保険普通保険約 款第10条。

30）自動車保険標準約款第 2 章第11条。

31）自動車保険標準約款第 4 章第11条。

32）ただし，後述のように無保険車傷害保険には本条項は入っていない。 
偶発的な外来の事故（ただし，疾病または体質的な要因を有する者が，軽微 な外因により発症しまたはその症状が増悪したときには，その軽微な外因は 急激かつ偶発的な外来の事故とはみなしません。）」と規定している。この但 書は，限定支払条項とはその位置づけや効力において違いがあるが，被保険 者が有する身体内部的要因を除外するという意味では，限定支払条項と同様 の方向性を有しているといえる。

\section{イ 判 例}

このように，限定支払条項と素因減額とは異なるものであるが，人身傷害 保険は自動車事故の損害賠償と密接な関係があるところから，限定支払条項 と素因減額との関係が争われることがある。以下のように，近時，この問題 を扱った下級審判例が出ている。

(判例 A) 大阪地判平成24年 9 月 19 日交民45巻 5 号1164頁 ${ }^{33)}$

本件は，人身傷害保険の被保険者がタクシー乗車中に追突され頸椎捻挫の 傷害を負ったが，その後，脊髄症状を発症し後遺障害等級表 5 級 2 号 $^{34)}$ の後 遺障害が残ったものである。被保険者にはもともと後縦勒带骨化症の素因が あって事故前には無症状であったが，事故を契機として経時的に頸椎後縦勒 带骨化症による脊髄症状を発症したものであると認定されている。被保険者 は人身傷害保険金を受け取ったが，さらに，加害者に対して損害賠償請求訴 訟を提起した。また，人身傷害保険金を支払った保険者も加害者に対して請 求権代位条項に基づき提訴した。本件の主な争点は，(1素因減額の可否およ びその割合，(2)人身傷害保険金が素因減額部分に優先的に填補されるか，で

33）判批として, 肥塚肇雄・損保研究76巻 4 号401頁（2015）がある。なお，藤 村和夫「人身傷害保険と素因減額」五十嵐敬喜 $=$ 近江幸治 $=$ 楜澤能生編 $\cdot$ 民事 法学の歴史と未来（田山輝明古稀記念）80頁以下（成文堂，2014）でも本判例 を検討している。

34）神経系統の機能または精神に著しい障害を残し，特に軽易な労務以外の労務 に服することができないもの。 
人身傷害保険における疾病の扱い

ある。

これに対して判旨は，11については5 割の素因減額を認め, (2)については, 人身傷害保険金は素因減額による減額部分から優先的に充当されると解釈す ることはできないとした。

(判例 B ) 大阪地判平成25年10月 3 日自保ジャ1918号158頁

本件は, 人身傷害保険の被保険者が歩行中に自転車と接触して転倒し, 左 環指関節脱臼で後遺障害等級表14級 9 号 ${ }^{35)}$ の後遺障害が残つたとして加害者 に損害賠償請求訴訟を提起したものである。被保険者は本件事故前に同じ左 環指関節に脱臼症状がありこれの手術を受けていたので，加害者は素因減額 を主張した。また，被保険者は本件事故について人身傷害保険金を受け取っ ており，この保険者も加害者に対して請求権代位に基づく請求をしている ${ }^{36)}$ 。 本件の主な争点は, (1)素因減額の可否およびその割合, 2)人身傷害保険金が 素因減額部分に優先的に填補されるか,である。

これに対して判旨は，(1)については 5 割の素因減額を認め, (2)については, 人身傷害保険金は素因減額部分に充当されるとした。

（判例 C）大阪地判平成25年11月21日交民46巻 6 号1479頁

本件は，人身傷害保険の被保険者が自動車を運転中に加害者が運転する自 動車に追突され，頸椎捻挫および背部打撲の傷害を被ったとして加害者に対 して損害賠償請求訴訟を提起したものである。被保険者は本件事故の直前ま でうつ病及びパニック障害の治療を継続してきており，このため，加害者は これによる心因性の素因減額を主張した。また，被保険者に対して人身傷害 保険金を支払つた保険者も，加害者に対して請求権代位にもとついて提訴し

35）局部に神経症状を残すもの。

36）人身傷害保険の対象は自動車または原動機付自転車の運行に起因する事故で あることが通常であり，本件において，自転車事故に対して人身傷害保険金が 支払われた経緯は不明である。 
ている。本件の主な争点は, (1)素因減額の可否およびその割合, (2)加害者の 被保険者に対する損害賠償額として素因減額後の金額から人身傷害保険金を 差し引くべきか, である。

これに対して判旨は，(1)については1割の素因減額を認め，(2)については， 素因減額後の金額から人身傷害保険金を差し引くことを認め, これによって 保険者の請求権代位による請求は支払った人身傷害保険金全額の範囲で認め た。

ウ 判例の検討

(a) 限定支払条項不適用の際の請求権代位の範囲

上記 3 判例に共通するのは，いずれも，被保険者（被害者）の加害者に対 する損害賠償請求及び人身傷害保険金を支払った保険者の請求権代位に基づ く請求の局面における問題であって，被保険者の人身傷害保険者に対する保 険金請求における限定支払条項の適用の可否が争われているわけではないこ とである。これは，そもそも，人身傷害保険金の支払段階では限定支払条項 を適用していないことによるのではないかと推測する37)。しかし，そうであ

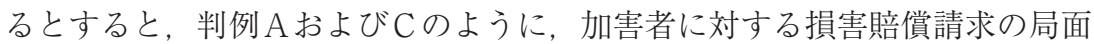
で，支払われた人身傷害保険金は素因減額部分には充当せずに加害者負担部 分に充当するということには疑問がある。

まず，限定支払条項が適用された場合を考える。この場合，保険金は加重 傷害部分（損害賠償の局面では素因減額の部分）を除いた部分に対する支払 いということであるから，それは素因減額の部分には充当されない（すなわ ち，加害者負担部分に充当される）と解することができよう ${ }^{38)}$ 。

37）判例 Cの判決文では人身傷害保険金の内訳が示されており，そこから限定支

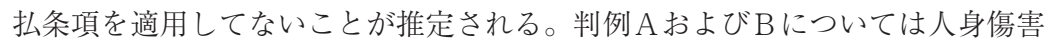
保険金の内容が不明であるが，限定支払条項を適用したという記述はない。

38）これに対して，限定支払条項が適用された場合でも，請求権代位の局面では 支払保険金は素因減額部分に優先充当すると解すべきとの説がある（榎本光宏 「判批」法曹時報66巻 6 号261頁 (2014)。 


\section{人身傷害保険における疾病の扱い}

これに対して，保険金支払の局面で限定支払条項を適用しなかった場合に は，保険金は加重傷害部分を含む全ての損害に対する支払いと見ることがで きるので，請求権代位の局面では，たまたま素因減額が行われたとしても， 差額説の観点から素因減額の部分に優先して充当されると解するべきである。 限定支払条項を適用しなかったということは，保険者としては，保険金支払 の段階では既存の疾病や障害が被保険者の傷害の程度に影響しなかったと判 断したわけであり，後に損害賠償の段階で裁判所によって素因減額が認めら れたからといって，その利益を享受するというのは信義に反すると考えられ る。

もっとも，人身傷害保険における算定損害額が保険金額を大幅に超過する ため，限定支払条項を適用してもしなくても支払保険金の額は変わらないと いう場合もありうる（判例 $\mathrm{A}$ はこのようなケースかもしれない）。しかし， この場合にも保険者としては被保険者に保険金を支払う段階で限定支払条項 適用の有無を伝えるべきであり ${ }^{39)}$ ，それが行われない場合には限定支払条項 は適用されなかったと判断されてもいたしかたあるまい。

\section{(b) 当事者間の合意}

結果的にみると, 判例 $\mathrm{A}, \mathrm{C}$ と判例 Bで結論が分かれた。判例 Bでは, 素 因減額が行われた場合には，人身傷害保険金は素因減額によって被保険者の 負担となった部分に充当されるという合意が保険者と被保険者との間にあっ たと認定されたが, 判例 $A$ ， Cではそのような合意は認定されなかったこと が，結論が分かれた原因である。

判例 B の保険者が如何なる意図でこのような合意を行ったのかは明確でな いが，限定支払条項を挿入している保険者の一般的な意図としては，上記の ように限定支払条項が適用される場合には人身傷害保険金は加害者の負担と なった部分に充当するということであろう。しかし，支払保険金額が少額で

39）人身傷害保険金支払実務においては, 保険金の額の算定過程を被保険者に提 示しているのではないかと思う。 
あってコスト的に請求権代位を行うことが考えられないような場合など，被 保険者の立場に配慮してこのような合意を行うことはあるかもしれないし， また，請求権代位における被保険者との間の無用な紛争を回避するという観 点から政策的に行うこともありうるであろう。

(c) 人身傷害保険における限定支払条項の適用

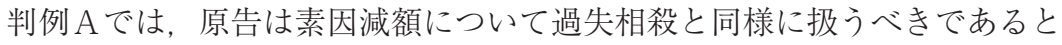
主張している。人身傷害保険はノーフォルト保険である以上，過失相殺を行 わないことは当然である。一方で, 人身傷害保険は急激かつ偶然な外来の事 故を保険事故とする傷害保険商品として構成されており, そこから疾病リス クを除外することになる。このような理由から，人身傷害保険においては過 失相殺と素因減額とを分けて扱うことになる。このような観点から限定支払 条項が挿入されているのであり，その文言上，素因減額を過失相殺と同様に 扱うことは無理である。もっとも，人身傷害保険に限定支払条項を置くこと 自体の適否については，後述のように議論がありうる。

\section{4. 小括}

\section{（1）サード・パーティ型制度からの填補との比較}

人身傷害保険はファースト・パーティ型のノーフォルト保険である。本保 険の商品性としては，ファースト・パーティ型保険であることにより被害者 は自分で付保した保険者から迅速な損害填補を受けることができるという手 続き面でのメリットもさることながら，ノーフォルト保険であることにより サード・パーティ型制度からの填補よりも手厚い給付が得られる（被害者自 身の過失の存在による減額が行われない）という填補内容面でのメリットが 最も重要な特長といえる。このような人身傷害保険の商品性からすると, 填 補内容についてサード・パーティ型制度より劣る部分があることは必ずしも 望ましいことではない。このような視点から，本章で取り上げた疾病が関与 するケースを再検討してみる。 


\section{人身傷害保険における疾病の扱い}

まず，自動車事故の原因に被保険者の疾病が関与していた場合を考える。 最高裁判例の解釈に従えば，このケースでは疾病免責条項の適用の問題とな るが，疾病と被保険者の被った損害との間に相当因果関係があれば保険者免 責となり，人身傷害保険からの填補は皆無となる。

この場合，自損事故であればサード・パーティ型制度からの填補もなされ ないので，この部分では人身傷害保険のカバーはサード・パーティ型制度の それと同じである。

一方，相手車が存在する場合には，前記のように相手車の運行供用者の責 任が発生する可能性があり，過失相殺の類推適用がなされたとしても，被保 険者としてはなんらかの填補を受けられる可能性はある。したがって, 全面 免責としている人身傷害保険のカバーは，この点ではサード・パーティ型制 度よりも劣っていると評価される場合がありうる。

次に，既存疾病によって被保険者の傷害が重篤になった場合はどうか。人 身傷害保険では限定支払条項が適用される結果, 既存疾病の影響がない部分 についてのみ填補が行われる。

これに対して，サード・パーティ型制度においては素因減額が適用される ことになり ${ }^{40)}$ ，その意味では，人身傷害保険のカバー範囲はサード・パーテ イ型制度による填補と同様であると評価されるようにみえる。しかし，前記 で示したように，素因減額においては素因の寄与割合に比例した減額がなさ れるのに対して，限定支払条項においてはかならずしも比例的な減額ではな く，結果的に素因の寄与割合よりも大きな減額がなされる可能性が大きい。 そして，その場合には人身傷害保険のカバーはサード・パーティ型制度から の填補に及ばないことになる。

40）ただし，自賠責保険においては実務上素因減額を行っていないとのことであ る。なお，自賠責保険の支払基準には因果関係の有無の判断が困難な場合には 5 割減額する（逆にいうと, 事故と傷害との因果関係が完全に立証されなくと も5 割は支払う）という規定があるが，これは素因減額とは局面を異にする。 


\section{（2）人身傷害保険における疾病の扱いの検討}

このような人身傷害保険のカバーにおける陥突（サード・パーテイ型制度 からの填補よりも劣る部分があること）は，前述のように人身傷害保険が傷 害保険の一種として構成されていることに由来する。そこでは, 急激かつ偶 然な外来の事故を保険事故とし, 疾病免責条項や限定支払条項を置くことで, 疾病の要素を徹底的に排除している。したがって，人身傷害保険のコンセプ トの観点から上記の陥穷を除去しょうとすれば，人身傷害保険の担保内容に （程度の差こそあれ）疾病リスクを持ちこまざるを得ず，基本的な商品設計 を変更する必要がある。

そもそも，傷害保険の商品であるからといって，保険事故の定義に急激性， 偶然性，外来性といういわゆる傷害事故三要件を規定し，また疾病免責条項 や限定支払条項を付することが必須のものであるわけではない。たとえば, 無保険車傷害保険は加害者が負担する損害賠償責任の額を支払うという約款 構成をとり，疾病免責条項や限定支払条項を置いていない。この保険では， 保険事故として「無保険自動車の所有，使用または管理に起因して」, 被保 険者が死亡しまたは後遺障害が生じることと定義しており ${ }^{41)}$ ，傷害事故三要 件は規定されていない。これは，対人賠償責任保険の保険事故である「被保 険自動車の所有，使用または管理に起因して他人の生命または身体を害する こと ${ }^{42)}$ という表現をそのまま採用したものである。

人身傷害保険の開発時，無保険車傷害保険と同様の保険事故の規定にする ことも可能であったと思われるが，結果的には一般的な傷害保険の保険事故 規定である傷害事故三要件方式を採用し，さらに，疾病免責条項や限定支払 条項を挿入することとなった ${ }^{43)}$ 。おそらく，これらの規定は傷害保険実務に おいて長年使用されてきており，その解釈についても判例や保険実務の積み

\footnotetext{
41）自動車保険標準約款第 3 章第 1 条。

42）自動車保険標準約款第 1 章 1 条。

43）ただし, 疾病免責条項は外来性に関する前揭最判平成19年 7 月 6 日および最 判平成19年10月19日が出た後に挿入された。
} 


\section{人身傷害保険における疾病の扱い}

重ねがあることを勘案したものと思われる。

しかし, 人身傷害保険の保険事故の規定については, 傷害事故三要件方式 よりも対人賠償責任保険方式の方が，ファースト・パーティ型ノーフォルト 保険によるサード・パーティ型制度からの填補の代替という人身傷害保険の コンセプトに，より適合するように思える。その意味で，人身傷害保険が登 場して以来，保険金支払に係る判例，実務も蓄積されてきた現在，あらため て傷害事故三要件方式を見直して独自の保険事故の定義を検討してもよいの ではないかと考える。また，無保険車傷害保険のように疾病免責条項や限定 支払条項を削除することも検討の余地があると思われる。このような商品に おいては，傷害保険でありながら結果的に疾病リスクを担保することになる が，それはあくまで自動車事故に関係するものに限定されるのであり，傷害 保険の本質論から否定されるべきとはいえないと考えられる。

仮に，約款構成を見直して人身傷害保険に自動車事故に伴う疾病リスクが 持ちこまれた場合，実務的に問題となるのは危険選択（アンダーライティン グ）である。人身傷害保険は自動車保険の一部として引き受けられており， 被保険者の疾病リスクについて危険選択を行うための告知義務（既往症等） が課されていない。このため，個々の被保険者が有するリスクに応じた保険 料率設定, すなわち, 給付反対給付均等の原則に基づく危険選択は不可能で ある。これを可能ならしめようとすれば自動車保険の引受時に疾病リスクに ついての告知義務を課すことになるが，そのような対応は実務的にみて望ま しいとは言い難い。

自動車事故に伴う疾病リスクの量は自動車事故全体のリスク量からみて極 めて限定されており，その意味で，人身傷害保険における疾病リスクに限れ ば，個別契約における危険選択の必要性がそれほど高いとは思えない。した がって，この問題は収支相等の原則に基づく全体としての保険料率水準の設 定の中で対応することが適当であると思われる。 